\title{
CULTIVATION OF THYRSOPTERIS ELEGANS
}

\author{
Andy Ensoll and Kate Matthews*
}

Thyrsopteris elegans Kunze is a monospecific genus of fern endemic to the Juan Fernandez Islands, off the coast of Chile. These islands have large numbers of alien invasive species and the native flora, including $T$. elegans which already has a very restricted distribution, is consequently under considerable threat. One of the largest examples of this species in cultivation in Britain grows at the Royal Botanic Garden Edinburgh and this paper describes its propagation and cultivation.

\section{INTRODUCTION}

Thyrsopteris elegans Kunze is a monospecific genus in the family Dicksoniaceae and occurs on a group of three islands $667 \mathrm{~km}$ off the coast of Chile known as the Juan Fernandez Islands. A terrestrial fern, it grows to $2 \mathrm{~m}$ and forms a small trunk in older specimens. It grows in the south western montane forests on the two largest of these islands, Masatierra and Masafuera. Masatierra lies nearest to the mainland and is $916 \mathrm{~m}$ at its highest point. Here, it forms the under storey to this dense forest at an altitude of 400-1000m (Perez-Garcia et al, [no date]) with Dicksonia berteriana and Blechnum spp. The dominant tree species in these forests include Cuminia spp. (Labiatae), Fagara spp. (Rutaceae), and Rhaphithamnus spp. (Verbenaceae). Masafuera lies a further $181 \mathrm{~km}$ away from the mainland and $D$. berteriana is replaced by $D$. externa which grows up to an altitude of at least $1050 \mathrm{~m}$. The highest point of this island is $1319 \mathrm{~m}$. The vegetation on these islands is unique not only in its high level of endemism $-62.5 \%$ of the 150 flowering plants and 50 fern species are endemic - but also in its species density and the density of these endemics, which is higher than on any other oceanic island (Bernadello and Steussy, 2001). T. elegans is one of 12 endemic genera.

\section{CLIMATE AND BACKGROUND}

While the climate on these islands is subtropical they are subject to the cooling effects of the south east trade winds and the Humboldt Current. This current brings cold waters from the bottom of the ocean near Antarctica to the surface of the Pacific along the coast of Chile. Average annual rainfall on the islands is $1061 \mathrm{~mm}$. However, this figure is variable according to altitude and aspect. On the higher mountain slopes such as those on which Thyrsopteris grows, rain can fall daily in short tropical bursts.

The English name for these islands is the Robinson Crusoe Islands from the novel Robinson Crusoe, written by Daniel Defoe in 1719. The plot of this novel was inspired

\footnotetext{
* Andy Ensoll is a Senior Horticulturist at the Royal Botanic Garden Edinburgh where he is responsible for the fern collection. Kate Matthews, also a Horticulturist at the Garden, is responsible for ferns and the Pelargonium collections. She is also Assistant Editor of Sibbaldia.

Address: Royal Botanic Garden Edinburgh, 20a Inverleith Row, Edinburgh, EH3 5LR.

Email: a.ensoll@rbge.org.uk and k.matthews@rbge.org.uk
} 
by the real life experience of Alexander Selkirk, a Scot from Largo in Fife. He was a 'privateer' on the ship Cinque Ports. Privateering was a form of legalised piracy whereby rival countries would pursue and take over the ships of other countries, in this case the English ship was after Spanish ships sailing to Chile. Their profits were made by commandeering the ship and selling the goods that it carried. Selkirk fell out with the Captain of the Cinque Ports when they were passing Masatierra and asked to be left ashore, hoping that the rest of the crew would follow him. However, they were wise enough to stay aboard (Mégroz, 1939). Luckily, Selkirk was sufficiently resourceful to stay alive on the island for over 4 years until he was picked up by a Captain Woodes Rogers in 1709. An account written by Captain Rogers suggests that there were already alien animal species on this island because Selkirk became expert at chasing goats for eating and clothing when his ammunition ran out, and he could no longer shoot them. It also mentions that he fed the cats in order to keep them close by him, thereby keeping rats away (Jennings, 2000).

Although there were alien animal species on the islands, it is unlikely that the large number of alien and invasive plants that thrive on the islands today were growing there in the 18th century. Some of them, such as Aristotelia chilensis, are native to the mainland while others, such as the bramble Rubus ulmifolius, are not native and are troublesome on the mainland as well. These plant and animal species that are not native to the islands, along with the human pressure, are highly detrimental to the balance of the islands' eco-system, thus putting the native flora under threat. In 1935 the Chilean Government designated the islands a National Park, and they are now administered by the authority for forestry and conservation, CONAF. They were also IUCN listed in the 'most threatened' category as a World Biosphere Reserve in 1977 (Bernardello and Steussy, 2001). Visitors to the islands report widespread destruction of the local flora due to the success of alien species (M. Gardner, pers.comm.) and it can therefore be inferred that this fern's environment, which already has an exceedingly limited distribution, is under great threat.

\section{Cultivation}

One of the largest examples of this species in cultivation in Britain is at the Royal Botanic Garden Edinburgh (RBGE) in one of the Garden's public display houses, the Fern House (Plate 1a). The house maintains a minimum night temperature of $10^{\circ} \mathrm{C}$ and an average day temperature of $13^{\circ} \mathrm{C}$ with the vents opening at $16^{\circ} \mathrm{C}$. It is growing in a raised bed with a westerly aspect in good light conditions in a substrate of loamy soil with $25 \%$ bark, and $5 \%$ added grit and it is mulched with coarse bark. A proprietary slow release fertiliser 'Enmag' is added at a rate of $150 \mathrm{~g}$ for every $100 \mathrm{l}$ of compost. 'Enmag' has a NPK ratio of 4:19:10 with added magnesium. The beds are fed with a balanced NPK liquid fertiliser twice monthly through the growing season using a Cameron Diluter and a top dressing of 'Enmag' is applied at the rate of $70 \mathrm{~g}$ per $\mathrm{m}^{2}$ in spring. The plant is never allowed to dry out. The most problematic pest is mealy bug which has been successfully treated in the past with a systemic insecticide.

The exact provenance of this plant, Accession Number 19925041, is unknown. What is known is that it was donated to RBGE by Glasgow Botanic Garden in 1992 as a vegetatively propagated plant and that it has been growing in the conditions described above since 1997. It has begun to form a small trunk and is expanding into the bed by sending out a number of stolons from which new crowns are developing. 
Plants may be propagated vegetatively by severing these stolons once they have sufficient roots to survive away from the parent plant and transplanting them to a free draining medium such as bark and perlite with no added fertiliser. They require a closed case with bottom heat to become established. This can take several months depending on the size and condition of the propagule in question.

To date, two individuals of 19925041 have been produced in this way. Once sufficient roots were produced they were potted on into another fairly open mix containing bark, John Innes No.1 for weight, a little gravel and the fertiliser Osmocote. Pots were fed with a balanced liquid feed throughout the growing season.

\section{Propagation FROM SPORES}

Spore production was unknown in RBGE's plants and in the plants growing in Glasgow until early spring 2002, when it was observed that all three of the Garden's plants began to sporulate at the same time, regardless of the size of the plants.

Spores are found at the base of the lamina of mature fronds on a short stem. The sori are held in 'bunches' which resemble those of grapes. The spherical sori split to release dark brown spores. When this first sporulation was noticed, many of the spores had already been shed. However, the sori were collected and spores remaining in them were sown on 5 March 2002.

\section{SOWING}

The collected spores were sown onto a spore sowing mixture consisting of $50 \%$ finely milled bark, $50 \%$ sphagnum moss peat with $5 \mathrm{ml}$ of 'Enmag' per 101 of mixture. This mixture was sterilised with two applications of boiling water in order to ensure thorough elimination of pathogens and weeds, and saturation of the mix. Sterilised pots were then enclosed in clean plastic bags and sealed. Once cool, spores were sown onto the surface of the pots using the method described below.

Spores are shaken on to a clean sheet of white paper. If spores are present a dark brown 'shadow' can be seen when the paper is held up to the light. The paper is shaken again to ensure that the spores are distributed as thinly as possible. If the density of the sown spores is too high they will be too crowded to develop correctly. The paper is then tapped sharply over the pot in order to release the spores on to the surface of the sowing mix. The pots are then covered in clingfilm and placed in a growing chamber which is kept at $22^{\circ} \mathrm{C}$ day and night with $12 / 12$ light regime.

A dense carpet of Thrysopteris gametophytes was produced after about three months. These were then 'patched off' to allow them to develop fully. When they become sexually mature fertilisation occurs. From this fertilisation, sporophytes are produced.

\section{Patching OFF}

Small patches approximately $2 \mathrm{~mm}$ in diameter were taken from the 'carpet' of gametophytes with fine tweezers and placed on the surface of a sterilised pot of sowing mixture. About $5-7 \mathrm{~mm}$ was left between patches to allow the gametophytes to grow. The pots were sealed again with clingfilm and placed back in the growing chamber. 
When the gametophytes had matured, the clingfilm was removed and they were sprayed with tepid water to aid fertilisation. The pots were resealed immediately with clingfilm to keep humidity levels high and to prevent contamination from pests or unwanted spores.

Sciarid fly is particularly destructive of gametophytes and young sporophytes because they feed on the tiny roots. At RBGE, Pinguicula moranensis, a large Mexican butterwort, is used to keep adults at bay.

Thyrsopteris sporophytes began to appear after about six months. Once they were beginning to push against the covering of clingfilm they were hardened off very gradually in the same growing chamber. It is essential that the pots do not dry out at any stage during these processes.

\section{HARDENING OFF AND GROWING ON}

The clingfilm was removed and pots were placed in a covered propagator with adjustable ventilation. This ventilation was gradually increased over a number of days. Once the plants had grown and the fronds were more robust they came out of the propagator and on to the benches of the growing chamber.

When sufficiently hardened off, the plants were individually potted up into an open mix containing two grades of bark, John Innes No.1, a little charcoal, grit and slow release fertiliser. They were replaced in the growing chamber for a while. When they were growing strongly and had developed a good root system they were transferred to a temperate glasshouse with a night temperature of $13^{\circ} \mathrm{C}$ and an average day temperature of $15^{\circ} \mathrm{C}$. The plants were potted on as they developed into similar compost with added slow release fertiliser. Approximately 200 plants have so far been produced in this way.

Plate 1c shows two pots of Thyrsopteris sporophytes before they were pricked out into individual pots. The pot on the left in Plate 1c shows the results of the first sowing. The largest leaves in this pot belong to Cyathea sp. which grow in close proximity to the Thyrsopteris plant in the fern house. Some smaller sporophytes of Thyrsopteris can be seen just above the rim of the pot. They have managed to grow eventually despite competition from the Cyathea sp.

The pot on the right in Plate 1c contains only Thyrsopteris sporophytes. This second sowing was made on 31 July 2002 from a second sporulation and the sori were collected just prior to shedding spores. All the sori were collected and washed under a cold tap to remove the unwanted spores of other species which may have landed on them. They were stored in a botanical envelope during which time the spores were shed. They were then sown on to the basic spore sowing compost with the method described above.

Most of the young plants now in cultivation at RBGE are the result of this sowing as this method of collecting and washing appears to ensure that the maximum number of spores are collected and that they are not contaminated by faster germinating species.

\section{OUTDOOR CULTIVATION}

It would be interesting to see this species more widely cultivated in botanic gardens and to know more about its climatic limitations. A large individual is currently planted outside at Logan Botanic Garden in Dumfries and Galloway (see Plate 1b) where the 
lowest winter temperatures are higher than those experienced on the east coast of Scotland. While Thyrsopteris is unlikely to prove reliably hardy in all but the mildest spots, Andy Ensoll speculates that some parts of southern Britain and Ireland may be suitable for outdoor cultivation, although some protection of the crown from frost and rain would have to be provided in the form of materials such as bracken fronds, straw or hessian.

\section{REFERENCES}

BERNARDELLO, GABRIEL and STEUSSY, TOD F, (2001) World Wildlife Fund Report. Terrestrial Ecoregions-Juan Fernandéz Islands temperate forests (NT0401).

JENNINGS, CHRIS islomania.com 2000.

MÉGROZ, R.L. (1939). The Real Robinson Crusoe. Being the life and strange surprising adventures of Alexander Selkirk of Largo, Fife, Mariner.

PEREZ-GARCIA, BLANCA, MENDOZA, ANICETO, RIBAL, RAMON and RICCI, MARCIA. [no date] Morphogenesis del gametofito del helecho Thyrsopteris elegans (Filicales:Thyrsopteridaceae) [On line] Available at $<\mathrm{http} / / \mathrm{www} . r b t . o t s . a c . c r / r e v i s t a s / 44-$ 3y45-1/perez.htm $>$ (Accessed January 2004). 
